\title{
Investment Protection in Offshore Energy Production: Bright Sides of Regime Interaction
}

\author{
Seline Trevisanut \\ University of Utrecht, The Netherlands \\ s.trevisanut@uu.nl \\ Nikolaos Giannopoulos \\ University of Utrecht, The Netherlands \\ n.giannopoulos@uu.nl
}

\begin{abstract}
At the international law level, the regulation of offshore energy projects does not fall neatly into one global regime. On the contrary, it is subject to a plethora of overlapping legal regimes, including the law of the sea, international environmental law, international economic law, and international energy law. The present article addresses the question how regime interaction affects investment protection in the offshore energy sector. Specifically, it investigates whether cross-fertilization between regimes also has 'positive' effects on the protection of investments in offshore energy or whether fragmentation consists of both a perceived and actual challenge. We submit that, even though regime interaction poses challenges to investment protection, the influence of the overlapping legal frameworks is not necessarily a 'threat' to investment protection. To the contrary, regime interaction can contribute to widen the objectives of international investment law.
\end{abstract}

\section{Keywords}

law of the sea - offshore energy investments - regime interaction - international investment law

* The research for this contribution has been conducted thanks to the financial support of the European Research Council under the European Union's Horizon 2020 research and innovation programme (Grant Agreement No 639070 - SUSTAINABLEOCEAN). 
As the global need for energy is increasing, the oceans are attracting unprecedented attention as a potential source of both traditional and renewable forms of energy. The offshore energy sector is expanding and economic activities related to energy production at sea are multiplying (e.g., oil and gas installations, deep seabed mining, marine renewable energy units, pipelines). The percentage of energy consumed in the world today coming from marine areas is rising exponentially and, accordingly, energy exploration and exploitation are moving further and deeper offshore. ${ }^{1} \mathrm{~A}$ unique characteristic of energy projects at sea is the apparent risk for widespread social, economic and environmental consequences, which such offshore activities bring forth in the event of major casualties. ${ }^{2}$ Without underestimating the risks of operational pollution, the potential for devastating transboundary environmental consequences in case of accidents related to offshore energy installations has been recently the focus of public and scholarly attention. ${ }^{3}$

In April 2010, a gas leak and a subsequent explosion occurred on the Deepwater Horizon oil rig in the Gulf of Mexico, resulting in the death of eleven workers and the world's largest oil spill at sea. ${ }^{4}$ Owing in large part to the great water depth of the well, it took approximately three months to stop the oil spills, with devastating consequences for the marine environment, the private economy, and the public budget of the entire region. According to the reports of the National Commission on the BP Deepwater Horizon Oil

1 Nengye Liu, 'Protection of the Marine Environment from Offshore Oil and Gas Activities' in Rosemary Rayfuse (ed), Research Handbook on International Marine Environmental Law (Edward Elgar 2015) 190.

2 Seline Trevisanut, 'Foreign Investments in the Offshore Energy Industry: Investment Protection v. Energy Security v. Protection of the Marine Environment' in Tulio Treves, Francesco Seatzu and Seline Trevisanut (eds), Foreign Investment, International Law and Common Concerns (Routledge 2013) 247, 247-48.

3 Will Amos, 'Development of Canadian Arctic Offshore Oil and Gas Drilling: Lessons from the Gulf of Mexico' (2011) RECIEL 39; Kyriaki Noussia, 'The BP Oil Spill-Environmental Pollution Liability and Other Legal Ramifications' (2011) EEELR 98; Tulio Scovazzi, 'Maritime Accidents with Particular Emphasis on Liability and Compensation for Damage from the Exploitation of Mineral Resources of the Seabed' in Andrea de Guttry and others (eds), International Disaster Response Law (Springer 2012) 287. The European Union (EU) also reacted to the Gulf of Mexico accident by issuing a Communication on Offshore Safety in October 2010, see European Commission, 'Facing the Challenge of the Safety of Offshore Oil and Gas Activities' $\operatorname{COM}(2010) 560$ final (12 October 2010).

4 BP plc, 'Deepwater Horizon Accident Investigation Report' (8 September 2010) <www .bp.com/content/dam/bp/pdf/sustainability/issue-reports/Deepwater_Horizon_Accident_ Investigation_Report.pdf $>$ accessed 8 May 2018. 
Spill and Offshore Drilling, the incident also had grave consequences for the offshore industry and other economic activities in the wider area, because it 'stopped all drilling in the Gulf for a period of time and cost virtually all oil and gas companies involved in the region a great deal of money. 5 The drilling accident served as a dramatic reminder of the immediate need for adequate international regulation of offshore energy operations in response to the currently fragmented, highly diverse and, thus, inadequate domestic regulation of the sector. ${ }^{6}$

At the international law level too, the regulation of offshore energy projects does not fall neatly into one global regime. On the contrary, it is subject to a plethora of overlapping legal regimes, mainly the law of the sea, international environmental law, international economic law, and international energy law. The fragmentation of the applicable legal framework also characterizes energy projects on land, which fall at least within the scope of application of the last three fields of international law just mentioned. The marine dimension of offshore energy projects and the consequent application of the law of the sea substantially change the international legal framework in terms of both applicable law and jurisdictional framework. Specifically, the law of the sea lays out the general legal framework for the establishment of such investments in energy projects at sea. Consequently, it is called to interact with the applicable rules of international environmental and international investment law. The international obligations stemming from the law of the sea and the multiple applicable international environmental agreements restrain the discretion of the coastal state to adopt laws and regulations regarding offshore energy investments. The overarching duty of states to exercise due diligence in preventing and mitigating the risk of significant harm to the marine environment ${ }^{7}$ with regards to activities within their jurisdiction or control might have an impact on the level of investment protection that can be afforded by the host State to the investors. This is of particular relevance when discussing recent

5 National Commission on the BP Deepwater Horizon Oil Spill and Offshore Drilling, 'Industry's Role in Supporting Health, Safety, and Environmental Standards: Options and Models for the Offshore Oil and Gas Sector' Staff Working Paper No 9 (2011) $13<$ https:// permanent.access.gpo.gov/gpo8589/Staff\%2oWorking\%20Paper\%2oIndustry\%2oRole.pdf> accessed 8 May 2018.

6 Maria Gavouneli, 'Offshore Installations: A Comprehensive Regime?' (2013) <www .mepielan-ebulletin.gr/default.aspx?pid=18\&CategoryId=4\&ArticleId=137\&Article $=$ Offsho re-Installations:-A-Compehensive-Regime> accessed 8 May 2018.

7 Tim Stephens and Duncan French, 'ILA Study Group on Due Diligence in International Law: Second Report' (July 2016) 18-20 <www.ila-hq.org/index.php/study-groups?study-group$\mathrm{sID}=63>$ accessed 8 May 2018. 
technological developments and the expansion of economic activities in areas remote from the coasts, within and beyond national jurisdiction. ${ }^{8}$

As drilling activities are moving into increasingly deep waters and extreme environments, the production of offshore energy requires long-term and capital-intensive investments in state-of-the-art infrastructure. However, the lack of a comprehensive and uniform legal regime regulating offshore energy activities undermines the legal certainty and predictability required to build the confidence of the industry. Making matters even more complicated, such long-term investments in infrastructure require large amounts of funding and, thus, necessarily involve a wide range of domestic and international financial institutions. The latter add an extra layer on the regulation of offshore energy projects, since they have the power to condition the funding of energy investments upon the satisfaction of certain environmental and social requirements. In this highly complex institutional and financial context, the need for stability in the relationship between investors and host States increases. ${ }^{9}$

The regulation of investments in offshore energy generation requires host States to perform a very delicate balancing exercise to align seemingly competing interests. On the one hand, their right to regulate investments in the sector is curtailed by their above-mentioned due diligence obligation to protect and preserve the marine environment within their jurisdiction. Particularly, States are under a due diligence responsibility to ensure that the activities of private investors will not cause significant harm to the marine environment. ${ }^{10}$ On the other hand, international investment agreements (IIAs) require States to ensure the protection of investments against non-commercial risks. Unsurprisingly, the simultaneous implementation of those overlapping international obligations of the host State can lead to normative conflicts and might have an impact on the standard of protection afforded to foreign investors.

8 We refer here to the imminent beginning of the exploration of deep-sea minerals in the Area, and to the on-going animated debates about bioprospecting in deep waters and offshore drilling in the Arctic. For an overview of ongoing discussions, see inter alia Alex D Rogers and others, 'Delving Deeper: Critical Challenges for 21st Century DeepSea Research' European Marine Board Position Paper 22 (2015) <www.marineboard.eu/ publication/delving-deeper-critical-challenges-21st-century-deep-sea-research $>$ accessed 8 May 2018.

9 Yulia Selivanova, 'The Energy Charter and the International Energy Governance' in Christoph Herrmann and Jörg Philipp Terhechte (eds), European Yearbook of International Economic Law 2012 (Springer 2012) 307, 315.

10 Responsibilities and Obligations of States Sponsoring Persons and Entities with Respect to Activities in the Area (Request for Advisory Opinion Submitted to the Seabed Disputes Chamber) (Advisory Opinion, 1 February 2011) ITLOS Reports 2011, paras 117-20. 
Against this background, the present article addresses the following question: how does regime interaction affect investment protection in the offshore energy sector? More specifically, this article investigates whether the interaction cross-fertilizes the involved regimes and thus whether regime interaction also has 'positive' effects on the protection of investments in offshore energy beyond potential and actual treaty conflicts. ${ }^{11}$ The analysis is fourfold. Part 1 focuses on the territorial scope of application of IIAs in order to establish whether, owing to the different types of jurisdiction (sovereignty/sovereign rights) the coastal state exercises in different marine areas, the application of international investment law differs from that on land. The analysis then zooms in on the interaction between investment protection and the jurisdictional framework provided by the law of the sea. In Part 2, our attention shifts to how the law of the sea and international environmental law impact the regulation of foreign investments in offshore energy projects. We focus on the main legal challenges for the protection of offshore energy investments posed by the interaction of the law of the sea and international environmental law. Despite these challenges, Part 2 also highlights the potential for mutual supportiveness between the protection of the marine environment and investment protection. In Part 3, we discuss whether and how the interactions analysed in Part 2 influence the settlement of disputes in this field. Particular attention is paid to the impact dispute settlement mechanisms other than investment arbitration have on investment protection. Finally, in Part 4, we submit that, even though regime interaction poses some challenges to investment protection, the influence of the overlapping legal frameworks is not necessarily a 'threat' to investment protection on all occasions. To the contrary, regime interaction can contribute to widen the objectives of international investment law; it has its 'bright sides'.

\section{The Substantive and Territorial Scope of Investment Protection} at Sea

Keeping in mind that the physical location of offshore energy projects distinguishes them from energy projects on land, we turn, first, to the question of whether they qualify as investments and thus fall under the scope of application of IIAs. To that end, we first assess to what extent investments in the production of offshore energy fall under the substantive scope of investment

11 Andreas Fischer-Lescano and Gunther Teubner, 'Regime-Collisions: The Vain Search for Legal Unity in the Fragmentation of Global Law' (2004) 25 Mich J Intl L 999. 
treaties (Section 2.1). We then discuss whether investment protection also extends to maritime zones and how the spatial location of those investments impacts the territorial reach of IIAs (Section 2.2).

\subsection{The Substantive Scope of Investment Protection at Sea}

There is no doubt that among the key provisions in any IIA are those defining the treaty's scope of application. This is because assets that fall outside the substantive scope of IIAs are not entitled to enjoy the benefits of the treaty's investment protection standards. ${ }^{12}$ In practice, most modern II As provide for a very wide asset-based definition of the term investment. ${ }^{13}$ Regardless of whether a treaty defines investment broadly or narrowly, offshore energy production infrastructure as an asset would fall quite easily within such definition. ${ }^{14}$

However, some IIAs may permit States to exclude from their scope of application critical sectors of the economy of the contracting States, including energy production. For example, Article 1101 of the North American Free Trade Agreement (NAFTA) reserves States the right to perform exclusively the economic activities set out in Annex III and to refuse to permit the establishment of foreign investments in such activities. This provision potentially authorizes States to exclude from the scope of application of Chapter 11 of NAFTA investments related to the exploration and exploitation of energy resources. In that spirit, Mexico has explicitly reserved its right to refuse the establishment of foreign investments, among others, in activities related to the exploration and exploitation of its energy resources and the generation of electricity because they are considered as strategic areas of the economy. ${ }^{15}$ The reservation clarifies that even when Mexico allows foreign investors to participate in activities related to energy exploration and exploitation, it is still allowed to impose restrictions on them that would otherwise be impermissible under the investment protection standards contained in NAFTA. ${ }^{16}$ Therefore, despite the very wide substantive scope of application of IIAs, it is possible that an IIA may limit investment protection in certain strategic parts of the economy. ${ }^{17}$ Such

\footnotetext{
12 Jeswald Salacuse, The Law of Investment Treaties (OUP 2010) 128.

13 UNCTAD, Bilateral Investment Treaties 1995-2006: Trends in Investment Rulemaking (United Nations 2007) 7 .

14 Attila Tanzi, 'International Law and Foreign Investment in Hydroelectric Industry: A Multidimensional Analysis' (2016) 18 Intl Comm L Rev 187; Trevisanut (n 1) 254.

15 North American Free Trade Agreement (signed 17 December 1992, entered into force 1 January 1994) (1993) 32 ILM 289, 605 (NAFTA) Annex III ('Activities Reserved to the State') s A, nos 1 and 2.

16 ibid s B.

17 UNCTAD, International Investment Agreements: Key Issues, vol I (United Nations 2004) 24.
} 
restrictions to the scope of application of investment protection can act as potential barriers to investments in offshore energy production.

By contrast, it is rather exceptional for IIAs to provide that, for an asset to qualify as protected investment, that asset must be made in a specified sector of the economy. To the knowledge of the present authors, the only example of an instrument dedicated specifically to investments in a specific economic sector is the Energy Charter Treaty (ECT). ${ }^{18}$ The ECT creates a comprehensive general legal framework for long-term cooperation in the energy sector. ${ }^{19}$ Its primary objective is to 'create a level playing field' 20 for investments in the energy sector, and to minimize the non-commercial risks associated with such investments. The cornerstone of the ECT are its provisions regarding the protection of foreign investments (Part III of the Treaty). ${ }^{21}$ To a large extent, these provisions reaffirm customary international law on foreign investment protection as articulated by a series of arbitral awards and IIAs. ${ }^{22}$ Under the ECT, there is no obligation of the Contracting Parties to open up their energy sector to foreign investors. On the contrary, Article 18(1) ECT ${ }^{23}$ reinforces the principle of permanent sovereignty over natural resources. ${ }^{24}$

The ECT's definition of the term 'investment' is quite inclusive so as to encompass virtually any right, property or interest in money or money's worth. In line with the treaty's single sectoral coverage, investments are required to

18 Energy Charter Treaty (Annex I of the Final Act of the European Energy Charter Conference) (signed 17 December 1994, entered into force 16 April 1998) (1995) 34 ILM 373 (ECT).

19 The countries of West Africa have adopted their own agreement in this area, the Economic Community of West African States (ECOWAS) Energy Protocol, which is substantially identical to the ECT, see ECOWAS Energy Protocol (31 January 2003) Doc A./P4/1/o3. Energy Charter Secretariat, The Energy Charter Treaty and Related Documents (Energy Charter Secretariat 2004) 14.

21 Kaj Hobér, 'Investment Arbitration and the Energy Charter Treaty' (2010) JIDS 155.

22 Andrei Konoplyanik and Thomas Wälde, 'Energy Charter Treaty and Its Role in International Energy' (2006) 24 JERL 534; Thomas Wälde, 'Energy Charter Treaty-Based Investment Arbitration: Controversial Issues (2004) 5 JWIT 378.

23 ECT (n 17) art 18(1) states: 'The Contracting Parties recognise state sovereignty and sovereign rights over energy resources. They reaffirm that these must be exercised in accordance with and subject to the rules of international law.

24 UNGA Res 1803 (XVII) (14 December 1962); UNGA Res 3171 (XXVIII) (17 December 1973). These UN General Assembly (GA) Resolutions recognized the fundamental right of States to exercise permanent sovereignty over the natural resources located on land within their boundaries, as well as in the seabed and the subsoil thereof within their national jurisdiction and in the superjacent waters, in the interest of their national development. It was declared that States have the right to explore and exploit freely their natural resources, and, accordingly, regulate foreign investments in the exploration and exploitation of such resources. 
be 'associated with an Economic Activity in the Energy Sector.'25 The second ECT's Understanding, which elaborates on the definition of Economic Activity in the Energy Sector, explicitly refers to

land transportation, distribution, storage and supply of Energy Materials and Products, e.g., by way of transmission and distribution grids and pipelines or dedicated rail lines, and construction of facilities for such, including the laying of oil, gas and coal-slurry pipelines.

It follows that the term 'associated with' is open-ended enough to broaden the treaty's scope regarding investments. ${ }^{26}$

Notwithstanding the considerable political risks faced by investors in the particularly strategic offshore energy sector, the high level of protection promised to foreign investors and access to independent dispute settlement mechanisms provided for by IIAs have significantly contributed to attracting foreign investments in the energy sector. ${ }^{27}$ Thus, it is not surprising that energy projects have frequently been a focal point of interest in international investment law. According to the recent caseload statistics of the International Centre for Settlement of Investment Disputes (ICSID), almost $45 \%$ of the new cases registered in 2017 under the Convention on the Settlement of Investment Disputes between States and Nationals of Other States (ICSID Convention) relate to the energy sector, with oil, gas and mining activities representing $24 \%$ of all ICSID cases in the same year. ${ }^{28}$ As a consequence, it can be safely argued that, in general, investments in energy projects fall within the substantive scope of application of most IIAs. Whether offshore energy projects fall within the territorial scope of application of IIAs will be addressed next.

25 For the definition of 'Economic Activity in the Energy Sector' see ECT (n 17) art 1(5); Limited Liability Company AMTO v Ukraine, SCC Case No 080/2005, Final Award (26 March 2008) paras 40-43 ("The associated activity of any alleged investment must be energy related, without itself needing to satisfy the definition in Article 1(5) of an Economic Activity in the Energy Sector.').

26 Arghyrios Fatouros, 'An International Legal Framework for Energy' (2007) 332 Recueil des Cours 418.

27 Markus Krajewski, 'The Impact of International Investment Agreements on Energy Regulation' in Herrmann and Terhechte (n 8) 343, 347-48.

28 ICSID, 'The ICSID Caseload-Statistics (Issue 2018-1)' (2018)<https://icsid.worldbank. org/en/Documents/resources/ICSID\%2oWeb\%20Stats\%202018-1(English).pdf> accessed 8 May 2018. 


\subsection{The Territorial Scope of Investment Protection at Sea}

Generally, an IIA covers only investments that are in the territory of one of the State parties to the agreement. ${ }^{29}$ For example, the territorial scope of the US Model BIT of 2012 includes 'investments in its territory of an investor of the other party.'30 Numerous model BITs contain a similar provision phrased in almost identical terms. Sometimes a territorial condition might also be contained in the definition of the term 'investment.'31 The rationale of this territorial limitation is to ensure that the host State benefits from the investments made within its territory. ${ }^{32}$ According to the Decision on Jurisdiction in SGS $v$ Philippines,

[t]he language is clear in requiring that investments be made 'in the territory of' the host State, and this requirement is underlined by other references to the territory of the host State in the BIT (see Preamble, para. 2, Articles II(1), (2), IV(1), (2), (3), VIII(2) and X(2)). In accordance with normal principles of treaty interpretation, investments made outside the territory of the Respondent State, however beneficial to it, would not be covered by the BIT. ${ }^{33}$

IIAs often include a definition of territory. While these provisions can vary widely in form, they tend to use similar language. For instance, many IIAs

29 For instance, NAFTA (n 14) art 1101 reads as follows: '1. This Chapter applies to measures adopted or maintained by a Party relating to: (a) investors of another Party; (b) investments of investors of another Party in the territory of the Party; and (c) with respect to Articles 1106 and 1114, all investments in the territory of the Party'. On the interpretation of the territorial requirement of investments under NAFTA, see Bayview Irrigation District et al $v$ United Mexican States, ICSID Case No ARB(AF)/05/1, Award (19 June 2007) paras 105-9.

$30 \quad 2012$ US Model Bilateral Investment Treaty (2012) art $1<$ www.state.gov/documents/organization/188371.pdf> accessed 8 May 2018.

31 For instance, the Treaty Between the United States of America and the Republic of Moldova Concerning the Encouragement and Reciprocal Protection of Investment (signed 21 April 1993, entered into force 25 November 1994) art 1(a) defines investment as '[e]very kind of investment in the territory of one Party owned or controlled directly or indirectly by ... companies of the other Party'. All referenced IIAs are, unless otherwise stated, available via UNCTAD's International Investment Agreements Navigator at <http://investmentpolicyhub.unctad.org/IIA> accessed 21 March 2018.

32 However, it should be mentioned that some IIAs do not contain language to that effect, see Christina Knahr, 'Investments "in the Territory" of the Host State' in Christina Binder and others (eds), International Investment Law for the 21st Century: Essays in Honour of Christoph Schreuer (OUP 2009) 42.

33 See SGS Société Générale de Surveillance SA v Republic of the Philippines, ICSID Case No $\mathrm{ARB} /$ o2/6, Decision on Jurisdiction (29 January 2004) para 99. 
define territory as including the 'territorial sea as well as those maritime areas, adjacent to the outer limit of the territorial sea over which the Contracting Party has jurisdiction or sovereign rights, pursuant to international law.'34 Since the conclusion of the United Nations Convention on the Law of the Sea (UNCLOS) in 1982, ${ }^{35}$ some IIAs refer explicitly to the functional maritime zones recognized by that Convention (i.e. the Exclusive Economic Zone (EEZ) and the continental shelf) in defining their territorial scope. ${ }^{36}$ For instance, NAFTA includes a remarkably elaborate definition of territory over which the contracting parties grant investment protection. Particularly, the Annex to Article 201(1) NAFTA reads as follows:

34 Denmark-Algeria BIT (signed 25 January 1999) art 1(4); Denmark-Argentina BIT (signed 6 November 1992) art 1(6); Denmark-Bosnia and Herzegovina BIT (signed 24 March 2004) art 1(4); Denmark-Bulgaria BIT (signed 14 April 1993) art 1(4); Denmark-Pakistan BIT (signed 18 July 1996) art 1(6); Denmark-Peru BIT (signed 21 November 1994) art 1(4); Denmark-Philippines BIT (signed 25 September 1997) art 1(6); Denmark-Poland BIT (signed 1 May 1990) art 1(4); Denmark-Russian Federation BIT (signed 4 November 1993) art 1(4); Denmark-Slovenia BIT (signed 12 May 1999) art 1(5); Denmark-Tanzania BIT (signed 22 April 1999) art 1(5); Denmark-Uganda BIT (signed 26 November 2001) art 1(6); Denmark-Ukraine BIT (signed 23 October 1992) art 1(4); Denmark-Venezuela BIT (signed 28 November 1994) art 1(4); Denmark-Vietnam BIT (signed 23 July 1993) art 1(4); United Kingdom-China BIT (signed 15 May 1986) art 1; Australia-China BIT (signed 11 July 1988) art 1; United Arab Emirates-China BIT (signed 1 July 1993) art 1(2); Algeria-China BIT (signed 17 October 1996) art 1(2); China-Kuwait BIT (signed 23 November 1985) art 1(67); China-Netherlands BIT (signed 26 November 2001) art 1; Belgo-Luxembourg-China BIT (signed 6 June 2005) art 1(4); Madagascar-China BIT (signed 21 November 2005) art 1(4), cited in Odysseas G Repousis, 'The Application of Investment Treaties to Overseas Territories and the Uncertain Provisional Application of the Energy Charter Treaty to Gibraltar' (2017) 32 ICSID Review 170, 172.

35 United Nations Convention on the Law of the Sea (signed 1o December 1982, entered into force 16 November 1994) 1833 UNTS 396 (UNCLOS).

36 See also Comprehensive Economic and Trade Agreement Between Canada and the European Union and its Member States (adopted 30 October 2016, provisionally entered into force 21 September 2017) [2017] OJ L 11/23 (CETA) art 1.3 on the geographical scope of application (amongst others of the investment protection provisions) reads:

Unless otherwise specified, this Agreement applies:

(a) for Canada, to:

(i) the land territory, air space, internal waters, and territorial sea of Canada;

(ii) the exclusive economic zone of Canada, as determined by its domestic law, consistent with Part V of the United Nations Convention on the Law of the Sea, done at Montego Bay on 10 December 1982 ('UNCLOS'); and,

(iii) the continental shelf of Canada, as determined by its domestic law, consistent with Part VI of UNCLOS .... 
territory means:

a) with respect to Canada, the territory to which its customs laws apply, including any areas beyond the territorial seas of Canada within which, in accordance with international law and its domestic law, Canada may exercise rights with respect to the seabed and subsoil and their natural resources;

b) with respect to Mexico, ... (ii) the islands, including the reefs and keys, in adjacent seas, (iii) the islands of Guadalupe and Revillagigedo situated in the Pacific Ocean, (iv) the continental shelf and the submarine shelf of such islands, keys and reefs, (v) the waters of the territorial seas, in accordance with international law, and its interior maritime waters, ... (vii) any areas beyond the territorial seas of Mexico within which, in accordance with international law, including the United Nations Convention on the Law of the Sea, and its domestic law, Mexico may exercise rights with respect to the seabed and subsoil and their natural resources; and c) with respect to the United States, ... (iii) any areas beyond the territorial seas of the United States within which, in accordance with international law and its domestic law, the United States may exercise rights with respect to the seabed and subsoil and their natural resources.

The elaborated reference to specific maritime zones in Article 201(1) NAFTA and the Annex thereto aptly illustrates that the purpose of the definition of territory in IIAs is not to describe the land territory of the Parties, but to indicate that the treaty applies to maritime zones (beyond the territorial sea) over which the host State exercises sovereign rights according to the international law of the sea. ${ }^{37}$ Therefore, in interpreting such a definition of territory the relevant rules of the law of the sea, which allocate sovereign rights to coastal States, must be taken into account. Particularly, taking into account Articles 2, 56 and 77 UNCLOS, ${ }^{38}$ the term 'territory' in NAFTA should be interpreted as including the continental shelf (even the extended continental shelf under the requirements provided in UNCLOS $)^{39}$ and, once it is proclaimed, the EEZ. ${ }^{40}$

37 UNCTAD, Bilateral Investment Treaties 1995-2006: Trends in Investment Rulemaking (United Nations 2007).

38 For further analysis of these articles see infra Part 3.

39 Pursuant to and within the conditions posed by art 76 UNCLOS, a coastal State can extend the outer limit of its continental shelf beyond 200 nautical miles to a maximum of 350 nautical miles.

40 Pursuant to Part V of UNCLOS, the exclusive economic zone (EEZ) is an area beyond and adjacent to the territorial sea in which the coastal State has 'sovereign rights for the 
Adopting a slightly differentiated wording, the ECT's investment protection provisions are applicable to investments located in or transiting through the 'Area' of another Contracting Party to the ECT. Article 1(10) ECT defines 'Area' as

(a) the territory under its sovereignty, it being understood that territory includes land, internal waters and the territorial sea; and (b) subject to and in accordance with the international law of the sea: the sea, sea-bed and its subsoil with regard to which that Contracting Party exercises sovereign rights and jurisdiction.

By referring to the sea, sea-bed, and subsoil over which the Contracting Party exercises sovereign rights and jurisdiction in the definition of the 'Area', the territorial scope of the ECT covers also the continental shelf and the EEZ of the contracting parties.

It is also noteworthy that such definitions of territory do not cover the high seas because, according to the law of the sea, States are not allowed to exercise any kind of sovereign rights over maritime areas beyond national jurisdiction. ${ }^{41}$ Even though this might seem speculative as no energy production at a commercial scale has taken place on the high seas yet, ${ }^{42}$ investment protection under those IIAs would not extend to any offshore energy project in the high seas. This is particularly true for those IIAs that explicitly refer to the rules of the law of the sea to describe their territorial scope of application. Only projects located in maritime zones that have been established according to the law of the sea are then protected. ${ }^{43}$ As a result, any excessive maritime claim will

purpose of exploring and exploiting, conserving and managing the natural resources, whether living or non-living, of the waters superjacent to the seabed and of the seabed and its subsoil, and with regard to other activities for the economic exploitation and exploration of the zone, such as the production of energy from the water, currents and winds', see UNCLOS art $56(1)(a)$. The EEZ does not exist ipso jure and cannot extend beyond 200 nautical miles from the coast.

41 UNCLOS, arts 87 and 89 .

42 There are ongoing discussions and related research projects on the (technological and legal) feasibility of wind farms and solar panels on the high seas; see inter alia the research project 'Solar Energy to Fuel at Sea: Marinization of Energy Transition' <www.kivi. nl/uploads/media/58ff66fo216a6/Sol2FaS_KIVI_Presentation_20170420_public.pdf> accessed 8 May 2018.

43 See explanatory footnote on the recent EU-Singapore Free Trade Agreement, which states that: "For greater certainty, investments made "in the territory of the other Party" shall include investments made in an exclusive economic zone or continental shelf, as provided in the United Nations Convention on the Law of the Sea of 10 December 1982', see European Commission, 'EU-Singapore FTA: Chapter 1: Objective and General Definitions' 
not be covered by the definition of 'territory' in an IIA. ${ }^{44}$ This is in turn particularly relevant for investments made in disputed maritime areas. ${ }^{45}$

Furthermore, in the case of IIAs that do not include a definition of territory it is questionable whether they cover investments in marine areas beyond the territorial sea. For instance, without containing any such definition, the Association of Southeast Asian Nations (ASEAN) Comprehensive Investment Agreement (ACIA) ${ }^{46}$ explicitly requires investments to be made within the territory of the contracting parties. For those IIAs that remain silent regarding their territorial scope of application, it is necessary to have recourse to general international law ${ }^{47}$ and, specifically, the law of treaties to examine whether the agreements in question also cover maritime zones beyond the territorial sea.

Pursuant to Article 29 of the Vienna Convention on the Law of Treaties (VCLT) '[u]nless a different intention appears from the treaty or is otherwise established, a treaty is binding upon each party in respect of its entire territory.'48 According to the International Law Commission's (ILC) Commentary on the Draft Articles on the Law of Treaties, the term territory refers to 'the land, the appurtenant territorial waters and the air space which constitute the territory of the State. ${ }^{49}$ Whereas the words 'land' and 'air space' do not raise any interpretation problems, the phrase 'appurtenant territorial waters' lacks clarity. If we accept that the word 'appurtenant' refers to the exercise of sovereignty, it should be interpreted as referring only to the internal waters and the territorial

(April 2018) <http://trade.ec.europa.eu/doclib/docs/2018/april/tradoc_156740.pdf> accessed 13 May 2018.

44 Nico Schrijver and Vid Prislan, 'The Netherlands' in Chester Brown (ed), Commentaries on Selected Model Investment Treaties (OUP 2013) 558.

45 Concerning investment protection in disputed maritime areas, see infra $\mathrm{n} 59$ and accompanying text.

46 The ASEAN Comprehensive Investment Agreement was signed on 26 February 2009, entered into force on 29 March 2012 and was amended by the 2013 Protocol to Amend the ASEAN Comprehensive Investment Agreement $<$ http://agreement.asean.org/> accessed 8 May 2018.

47 Regarding the role of general international law in special regimes, see International Law Commission (ILC), 'Fragmentation of International Law: Difficulties Arising from the Diversification and Expansion of International Law - Conclusions of the Work of the Study Group' UN GAOR 61st Session Supp No 10, UN Doc A/61/10 (2006) 407, 410, para 15.

48 Vienna Convention on the Law of Treaties (adopted 23 May 1969, entered into force 27 January 1980) 1155 UNTS 331 (VCLT) art 29. The provision is regarded as setting out a rule of customary international law, see Oliver Dörr and Kirsten Schmalenbach (eds), Vienna Convention on the Law of Treaties: A Commentary (Springer 2012) 490. The tribunal in the Fedax case gave a very broad interpretation of territoriality, based upon the fact that the BIT under its scrutiny included a lenient territorial requirement, see Fedax $N V v$ The Republic of Venezuela, ICSID Case No ARB/96/3, Award (9 March 1998) para 41. ILC, 'Draft Articles on the Law of Treaties with Commentaries' (1966) art 25, para 3. 
sea of the coastal State. ${ }^{50}$ Following such a strict interpretation of the term 'territory', the EEZ and the continental shelf over which the coastal State exercises only 'sovereign rights' would remain outside the geographical scope of application of IIAs that are silent on their territorial application, as shown in the example of the ACIA. ${ }^{51}$

Scholars have supported the view that the term 'territory' is intrinsically linked to the the exercise of jurisdiction by the State. Specifically, according to Brownlie: 'courts are very ready to equate 'territory' with the actual and effective exercise of jurisdiction. ${ }^{52}$ In the context of the law of the sea, a coastal State exercises sovereign rights and jurisdiction over its continental shelf, and once proclaimed, the EEZ. Therefore, pursuant to this interpretation of 'territory', the EEZ and the continental shelf would fall within the geographical scope of application of IIAs, even when the agreement in question does do not explicitly refer to these maritime zones. This argument seems to be reinforced by a teleological interpretation of IIAs. According to the general rules of treaty interpretation, as codified in Article 31(1) of the VCLT, any IIA should be interpreted 'in good faith in accordance with the ordinary meaning to be given to the terms of the treaty in their context and in the light of its object and purpose. ${ }^{53}$ Despite different wording used by various IIAs in relation to their territorial scope of application, their primary purpose is to promote foreign investments and to advance economic cooperation between States parties. ${ }^{54}$ Thus, the wider the territorial scope of application of the treaty, the more the purpose and object of the treaty are respected. ${ }^{55}$

$50 \quad$ Dörr and Schmalenbach (n 47) 497.

51 The EEZ as a new sui generis maritime zone was a development in the law of the sea introduced by UNCLOS in 1982 and for that reason it could not have been taken into consideration by the ILC at the time of drafting the Articles on the Law of Treaties. On the contrary, the exercise of sovereign rights over the natural resources of the continental shelf by coastal States, enshrined in art 2 of the Convention on the Continental Shelf (adopted 29 April 1958, entered into force 10 June 1964) 499 UNTS 311, was already recognised as a rule of customary international law.

$5^{2}$ Ian Brownlie, Principles of Public International Law (6th edn, OUP 2003) 112.

53 Thomas Wälde, 'Interpreting Investment Agreements: Experiences and Examples' in Binder and others (n 31) 751-68; Salacuse (n 11) 146-48.

54 For instance, the tribunal in the $L G \& E$ case relied on the preamble of the BIT to conclude that the purpose and object of the treaty was to promote economic cooperation and 'stimulate the flow of private capitals and the economic development of the parties', see LG\&E Energy Corp et alv The Argentine Republic, ICSID Case No ARB/02/01, Decision on Liability (26 September 2006) para 124.

55 Sanum Investments Limited $v$ Lao People's Democratic Republic, UNCITRAL, PCA Case No 2013-13, Award on Jurisdiction (13 December 2013) para 240 ('In fact, the larger scope the Treaty has, the better fulfilled the purposes of the Treaty are in this case: more investors 
In addition, Article 31(3) of the VCLT prescribes that treaties shall be interpreted taking into account subsequent agreements and the practice of States with regard to their interpretation. Therefore, the term 'territory' should be interpreted taking due account of the parties' subsequent agreements and practice. As already described, States have included very elaborate definitions of the term 'territory' in the most recent IIAs and in many model BITs. It is arguable that these subsequent IIAs, which explicitly include the EEZ and the continental shelf of the State parties within their geographical scope of application, constitute subsequent practice for the purposes of interpretation of the term territory. ${ }^{56}$

To date, the textual differences among IIAs have not led to any significant problems in State practice. While a relatively large number of awards have already addressed the questions of what constitutes an 'investment', the territorial requirement has not been under scrutiny until recently. In a few proceedings brought before ICSID tribunals, respondent States have argued that the territorial requirement had not been met because the investment was not physically located in their territory. ${ }^{57}$ Until now, only two investor-State arbitration cases have been dismissed on the grounds that the investments fell outside the scope of territorial application of the IIA. ${ }^{58}$ However, these cases did not concern investments located in marine areas. ${ }^{59}$

Without going into details, it is worth mentioning that further and more complicated issues on the application of IIAs arise in disputed maritime

- who would not otherwise be protected - are internationally protected, and the economic cooperation benefits a larger territory that would otherwise not receive such benefit.').

56 In this sense see James Harrison, 'International Investment Law and the Regulation of the Seabed' in Catherine Banet (ed), The Law of the Seabed (Brill) (forthcoming).

57 Christoph Schreuer and others, The ICSID Convention: A Commentary (2nd edn, CUP 2009) art 25 paras 191-98; Ceskoslovenska Obchodni Banka v The Slovak Republic, ICSID Case No ARB/97/4, Decision on Jurisdiction (24 May 1999) paras 78-79; Abaclat and Others $v$ Argentine Republic, ICSID Case No ARB/07/5, Decision on Jurisdiction (4 August 2011) para 234.

58 Bayview Irrigation District et al v Mexico, ICSID Case No ARB(AF)/05/1, Award (19 June 2007) paras 93-124; Canadian Cattlemen for Fair Trade $v$ United States, NAFTA/ UNCITRAL, Award on Jurisdiction (28 January 2008) para 233.

59 By contrast, disputes relating to investments in marine areas have not so far addressed the territorial requirement. For instance, in the case of Mobil and Murphy Oilv Canada, there was no dispute between the parties regarding whether an investment on the continental shelf of Canada fell within the scope of geographical coverage of Canada. However, as already discussed, NAFTA includes an elaborate definition of the term territory, which would not allow any ambiguity about its geographical coverage. See Mobil and Murphy Oil v Canada, ICSID Case No ARB(AF)/07/4, Decision on Liability and Principles of Quantum (22 May 2012). See also Harrison ( $\mathrm{n}_{55}$ ). 
areas. ${ }^{60}$ Offshore energy production around the Falklands Islands serves as an example. ${ }^{61}$ It is under debate whether investments in the territorial sea of the Falklands fall under the territorial scope of application of the United Kingdom's or Argentina's IIAs. Theoretically, an investor could initiate arbitral proceedings against both States simultaneously and the tribunals could be required to address the sovereignty question. However, it could be contested whether such type of dispute can be resolved by an investment tribunal in view of its limited jurisdiction under the IIA in question. Similar issues would arise in relation to Gibraltar (between the United Kingdom and Spain). Harrison sustains that such a situation, where sovereignty over territory is contested, would not result in denial of jurisdiction by the arbitral tribunal, which could deprive the investor of protection. The investment tribunal could actually apply the principle of ex facti jus oritur, 'so that the exercise of de facto sovereign rights in a contested area could be sufficient to establish that an investment was in the territory or maritime zone of the state. ${ }^{62}$ The concept of territory would then shift towards the concept of de facto jurisdiction, in a manner similar to the field of human rights. ${ }^{63}$ In the view of the present authors, this shift cannot be presumed and does not seem to be supported by treaty practice, as mentioned above.

Remarkably, many provisions of IIAs on the definition of territory include a renvoi to the law of the sea, making explicit reference to the relevant rules of the international law of the sea in general and sometimes to UNCLOS specifically. Besides reaffirming the role of UNCLOS as a comprehensive 'legal framework within which all activities in the oceans and seas must be carried out, ${ }^{\prime} 64$ those references illustrate the necessary normative interaction between IIAs and the international law of the sea when it comes to investments located in offshore areas. Their interaction becomes essential at the stage of interpreting of IIAs in order to clarify their geographical scope of application. As discussed above, IIAs, by interacting with the law of the sea at the level of interpretation, can expand their territorial application to marine areas, such as the EEZ and the (extended) continental shelf. This is in line with their object and purpose, which primarily is to provide wider protection to investments and cultivate

$60 \quad$ On this specific issue see the paper by Peter Tzeng, 'Investment Protection in Disputed Maritime Areas' (2018) 19 JWIT 828 (in this Special Issue).

61 Michael Waibel, 'Oil Exploration Around the Falklands (Malvinas)' (EJIL:Talk!, 13 August 2012) <www.ejiltalk.org/oil-exploration-around-the-falklands-malvinas/> accessed 13 May 2018.

62 Harrison ( $\left.\mathrm{n}_{55}\right) 10$.

63 Hugh King, 'The Extraterritorial Human Rights Obligations of States' (2009) 9(4) Human Rights L Rev 521 .

64 Oceans and the Law of the Sea (Draft Res) UN Doc A/71/L.26 (25 November 2016) 2. 
economic cooperation between the contracting States. By referring explicitly to the applicable rules of the law of the sea, IIAs incorporate any subsequent normative developments in the law of the sea that could alter the current limits of marine areas over which the coastal State exercises sovereign rights or jurisdiction. Such interaction between the two fields of law, i.e., textual references to the law of the sea in IIAs, consequently reinforces the geographical scope of protection of IIAs with regard to offshore energy investments.

\section{$3 \quad$ Investment Protection of Offshore Energy Projects in Context}

The IIAs that grant protection to investments in offshore energy production do not exist in a legal vacuum, neither do they consist of self-contained international regimes. Due to the physical location of offshore energy projects and their potential impact on the marine environment, the law of the sea and international environmental law play an important role in the regulation of investments in offshore energy production. In other words, the law of the sea and international environmental law provide a dense normative context in which offshore energy investments operate.

First, we offer a brief overview of the jurisdictional framework of UNCLOS, which provides the investors with legal certainty with respect to the host States rights over offshore energy resources in different maritime areas (Section 3.1). Moving to the substantive obligations of States with regards to offshore energy activities, we then discuss the environmental obligations of States under UNCLOS and international environmental law to highlight their potential effect on the protection of investments at sea (Section 3.2). In this context, we argue that investment protection faces multiple legal challenges, which arise out of the interaction between international investment obligations of the host State and obligations under the aforementioned regimes (Section 3.3).

Yet, this interaction also presents some positive elements, some bright sides. Indeed, the law of the sea provides for the jurisdictional framework of maritime activities, which clarifies who can do what and where also in relation to offshore energy projects. Specifically, alongside with international environmental law, it substantiates some of the procedural obligations, which in practice fall on the investors in offshore energy projects. Therefore, we posit that under certain circumstances the protection of the marine environment and the protection of investments can be mutually supportive objectives, facilitating the synergetic interaction between international investment law, on the one side, and international environmental law and the law of the sea, on the other side (Section 3.4). 


\subsection{The Jurisdictional Framework of UNCLOS Related to Offshore Energy Investments}

As described above, UNCLOS serves as the comprehensive legal framework regulating all activities at sea. Primarily, it divides oceans into zones, where different (spatial) rights and obligations are allocated to States and other users of the sea. In the period following the Second World War, the vital interest of States to explore and exploit their marine natural resources has influenced heavily the drafting of the Convention and the zonal demarcation of the oceans. To that end, rights and duties recognized therein have a direct bearing on the regulation of energy-related activities at sea. Importantly, in the territorial sea, the EEZ, and the continental shelf, ${ }^{65}$ coastal States are vested with a spectrum of exclusive rights for the exploration and exploitation of natural resources and the commissioning of infrastructure for the prospecting, exploration, or exploitation of energy resources. At the same time, in the EEZ other States enjoy certain freedoms that are equally important for the completion of the energy chain, notably, navigational freedoms and the freedom of laying submarine cables and pipelines that are essential for the transport, transmission, or distribution of energy resources and products.

In the territorial sea (up to 12 nautical miles), coastal States have the exclusive right to exploit the marine energy resources. This exclusive right is subject only to the coastal State's obligation not to hamper the right of innocent passage and relevant obligations stemming from other applicable rules of international law. ${ }^{66}$ In addition, under customary international law, as codified by UNCLOS, coastal States are entitled to a continental shelf up to $200 \mathrm{~nm}$, and under specific circumstances, to an extended continental shelf. ${ }^{67}$ Moving further from the shore, coastal State authority decreases. ${ }^{68}$ Beyond the territorial sea, the coastal state 'exercises over the continental shelf sovereign rights for the purpose of exploring and exploiting its natural resources', and not full sovereignty. ${ }^{69}$ The sovereign rights of the coastal State on its continental shelf

65 For the purposes of this paper, we do not extend the analysis to the high seas, where potential future claims for natural resources would be satisfied, pursuant to the freedoms of the high seas on areas beyond state jurisdiction, on a first-come first-served basis applies or to the 'Area', where exploration and exploitation activities are authorised and regulated exclusively by the International Seabed Authority.

66 UNCLOS, arts 2, 19-27.

67 UNCLOS, art 77(1).

68 Maria Gavouneli, 'Energy Installations in the Marine Environment' in Jill Barret and Richard Barnes (eds), UNCLOS as a Living Treaty (BIICL 2016) 187, 189.

69 On the debate about the use of terminology during the drafting of articles on law of the sea by the ILC, see Richard Barnes, Property Rights and Natural Resources (Hart 2009) 273. 
exist ipso jure, as they do not need to be proclaimed. ${ }^{70}$ Furthermore, they are 'exclusive', meaning that no one may undertake exploration and exploitation of natural resources of the continental shelf without the express consent of the coastal State. ${ }^{71}$ The Convention thus confers on coastal States the exclusive right to authorize and regulate drilling on the continental shelf for all purposes (including the exploration and exploitation of natural resources). ${ }^{72}$ However, the exercise of their sovereign rights is not limitless, since they are obliged to act in accordance with the provisions concerning the prevention, reduction and control of pollution of the marine environment from seabed activities subject to national jurisdiction. ${ }^{73}$ In that sense, the coastal State obtains the exclusive right to explore and exploit the natural resources found in its continental shelf, and to regulate the conduct of such activities; but at the same time its freedom is restrained by its duty to protect and preserve the marine environment.

Similarly, when a State has proclaimed an EEZ, ${ }^{74}$ it enjoys sovereign rights 'for the purpose of exploring and exploiting, conserving and managing the natural resources, ... with regard to other activities for the economic exploitation and exploration of the zone, such as the production of energy from the water, currents and winds. ${ }^{175}$ Within both the EEZ and the continental shelf, ${ }^{76}$ coastal States have the exclusive right to authorise and regulate the construction, operation and use of all artificial islands ${ }^{77}$ and installations and structures which: 'a) are used for the exploration and exploitation of natural resources and other economic purposes, and b) may interfere with the exercise of the rights of the coastal state in the zone. ${ }^{78}$ Since the establishment of any offshore installation by third States would easily qualify as an interference with the exercise of the

70 According to Sir Hersch Lauterpacht the right of States to exercise sovereign rights over the continental shelf is legally based on the doctrine of natural prolongation or contiguity of the continental shelf, see Hersch Lauterpacht, 'Sovereignty over Submarine Areas' (1950) 27 BYBIL 376, 423-31.

71 Yoshifumi Tanaka, The International Law of the Sea (2nd edn, CUP 2015) 147-48.

72 UNCLOS, art 81.

73 UNCLOS, art 208.

74 On the contrary, sovereign rights on the continental shelf 'do not depend on occupation, effective or notional, or on any express proclamation', see UNCLOS, art 77(3).

75 UNCLOS, art 56(1)(a).

76 Normally, the EEZ and the continental shelf regimes will apply simultaneously in one marine area, up to 200 nautical miles.

77 However, artificial islands do not possess the status of islands and for this reason they cannot generate entitlements to marine areas around them, see UNCLOS, art 6o(7). By contrast, islands do generate such areas, pursuant to ibid art 121(2).

78 UNCLOS, arts 6o(1) and 80. 
sovereign rights of the coastal State, the latter has the exclusive right regarding the construction and exploitation of any type of offshore installations in its EEZ. Whereas the terms 'installations' and 'structures' are not defined in the Convention, it is safe to conclude that the coastal State retains exclusive jurisdiction over any infrastructure used to explore and exploit marine energy resources, both fossil and renewable, in the EEZ and the continental shelf. ${ }^{79}$ Additionally, UNCLOS provides for coastal State jurisdiction over cables and pipelines constructed or used in connection with the exploration and exploitation of its continental shelf. 80

Nevertheless, due to the sui generis nature ${ }^{81}$ of the EEZ, all States, whether coastal or land-locked, enjoy the freedoms of navigation and overflight, and of the laying of submarine cables and pipelines, as well as other internationally lawful activities related to those freedoms. ${ }^{82}$ Third States acting within the EEZ of a coastal State are required to exercise the freedoms in question, while having 'due regard to the rights and duties of the coastal State. ${ }^{83}$ Accordingly, the coastal State in exercising its sovereign rights and duties in the EEZ also needs to have due regard for the rights and obligations of third States.

Under UNCLOS, the concept of 'due regard' plays a key role in the balancing of competing interests between States. ${ }^{84}$ For instance, artificial islands and offshore structures may not be established where they will interfere with recognised sea lanes essential to international navigation. ${ }^{85}$ Bearing in mind the balance of competing interests among coastal and third States, the Convention also clarifies that the exercise of sovereign rights of the coastal State on the continental shelf must not infringe or result in any unjustifiable interference with navigation and other freedoms of third States. ${ }^{86}$ It remains debated whether 'due regard', as an obligation which binds both coastal and

79 Alex Oude Elferink, 'Artificial Islands, Installations and Structures' in Rüdiger Wolfrum (ed), Max Planck Encyclopedia of Public International Law (online edn, 2013).

8 o UNCLOS, art 79(4). However, all States are entitled to lay submarine cables and pipelines on the continental shelf and the coastal state retains the final decision on the delineation of the course of their placement. See Markos Karavias, 'Submarine Cables and Pipelines: The Protection of Investors Under International Law' (2018) 19 JWIT 860 (in this Special Issue).

81 The EEZ does not belong either to the territorial sea or the high seas, but has been described as tertium genus between those maritime zones, see Barnes (n 68) 296.

82 UNCLOS, art $58(1)$. See also Tanaka (n 70$) 135$.

83 UNCLOS, art $58(3)$.

84 See UNCLOS, arts 2(3), 34(2), 56(2), $78(2), 87(2)$.

85 UNCLOS, art $60(7)$.

86 UNCLOS, art $78(2)$. 
third States, balances acts in a neutral way or whether the Convention prioritizes the rights of the coastal State in the EEZ. ${ }^{87}$

The definition of 'due regard' 88 to the rights and duties of the other States is increasingly important because of the expansion of offshore energy activities, which inevitably increases demands of exclusive presence of offshore infrastructures in marine areas. ${ }^{89}$ Offshore energy installations sometimes require exclusive use of large marine areas, thus, creating potential conflicts with the right of third States to enjoy their freedoms in the EEZ. ${ }^{90}$ For instance, commercial-scale offshore renewable energy generation is likely to be contingent upon the presence of a considerable number of installations in an extended marine area. ${ }^{91}$ Presumably, such a development has the potential to conflict with other traditional lawful uses of the sea, such as navigation or fishing. ${ }^{92}$

In general, the stable jurisdictional framework of UNCLOS provides investors with legal certainty regarding the rights of coastal States in relation to offshore energy resources. But while the rules on jurisdiction do not pose any particular challenge for investments, there is a potential clash between the protection of investments and environmental protection as is explained in the following part.

\subsection{The Environmental Framework of UNCLOS Related to Offshore Energy Investments}

As noted above, the coastal State's exclusive rights to exploit its natural resources in marine areas within its jurisdiction ${ }^{93}$ must be exercised in accordance

87 Julia Gaunce, "The South China Sea Award and the Duty of "Due Regard" Under the United Nations Law of the Sea Convention' (2016) <http://ablawg.ca/2016/og/o8/southchina-sea-and-duty-of-due-regard/> accessed 13 May 2018.

88 The obligation to have due regard to rights and obligations of third states is reflecting the lack of sovereignty of the coastal state in the EEZ. It only enjoys sovereign rights, which preclude it from interfering with other lawful uses of the zone by third states.

89 Maria Gavouneli, 'Offshore Energy: Troubled Waters in the Eastern Mediterranean Sea' in Harry N Scheiber, James Kraska and Moon-Sang Kwon (eds), Science, Technology and New Challenges to Ocean Law (Martinus Nijhoff 2015) 253, 254-55.

9o Hossein Esmaeili, 'The Conflict Between the Establishment and Operation of Offshore Oil Installations, Navigation and Other Uses of the Sea in International Law' (2002) 11 Intl Energy L \& Tax Rev 286.

91 Gavouneli (n 88) 254.

92 Esmaeili (n 89).

93 Besides the general provisions of Part XII, the Convention also contains specific provisions for the protection of the marine environment from activities taking place in the 'Area', see UNCLOS, arts 145, 209, 215, 221. 
with its duty to protect and preserve the marine environment. ${ }^{94}$ Negotiated as an interlocking package deal, ${ }^{95}$ UNCLOS has established a sophisticated system for the protection and preservation of the marine environment, which is mostly found in the provisions of Part XII. ${ }^{96}$ Article 192 UNCLOS creates a general and comprehensive obligation of all States to preserve and protect the marine environment. This obligation is meant to apply to the oceans as a whole ${ }^{97}$ and covers all possible sources of marine pollution and other potential environmental harms. ${ }^{98}$ It needs to be stressed that, while the international legal framework for the protection of the marine environment is anchored in UNCLOS, it is complemented by a patchwork of relevant instruments at the global and regional levels, which go beyond the scope of the present article. ${ }^{99}$

According to the recent Award by an UNCLOS Annex VII tribunal in the South China Sea Arbitration Between the Republic of the Philippines and The People's Republic of China (SCS Award), Article 192 UNCLOS, despite its vague phrasing, imposes a duty on States and needs to be read in conjunction with the other provisions of Part XII and other applicable rules of international law. ${ }^{100}$ The Tribunal interpreted the provision as encompassing both a positive obligation of States to take active measures to protect and preserve the marine environment and a negative duty to refrain from degrading the marine

94 The duty of states to protect and preserve the marine environment has arguably become part of customary law, see Tanaka (n 70) 34 .

95 Patricia Birnie, Alan Boyle and Catherine Redgwell, International Law and the Environment (3rd edn, OUP 2009) 382.

96 Despite the fact that the whole Part XII is dedicated to the protection and preservation of the marine environment, the Convention contains many more provisions on the same subject in other Parts and, in particular, in Part V on the EEZ and Part VII on the high seas.

97 ITLOS, Request for an Advisory Opinion Submitted by the Sub-Regional Fisheries Commission (SRFC) (Advisory Opinion, 2 April 2015) ITLOS Reports 2015, para 120.

98 Pursuant to UNCLOS art 194(1), States 'shall take, individually or jointly as appropriate, all measures consistent with this Convention that are necessary to prevent, reduce and control pollution of the marine environment from any source, using for this purpose the best practicable means at their disposal and in accordance with their capabilities.'

99 See, inter alia, Seline Trevisanut, 'La Convention des Nations Unies sur le droit de la mer et le droit de l'environnement: Développement intrasystémique et renvoi intersystémique' in Hélène Ruiz Fabri and Lorenzo Gradoni (eds), La circulation des concepts juridiques: Le droit international de l'environnement entre mondialisation et fragmentation (Société de législation comparée 2009) 397-426.

100 The Republic of the Philippines $v$ The People's Republic of China (South China Sea Arbitration), PCA Case No 2013-19, Award (12 July 2016) para 941. On the environmental law aspects of the award, see Ilias Plakokefalos, 'Environmental Law Aspects of the Arbitral Tribunal Award in the South China Sea Dispute' (2016) <https://papers.ssrn.com/ sol3/papers.cfm?abstract_id=2880624> accessed 13 May 2018. 
environment. Embedding the obligation in the context of international environmental law, the Tribunal held that States are required to 'ensure that activities within their jurisdiction and control respect the environment of other States or of areas beyond national control.'101

Referring to the judgement of the International Court of Justice (ICJ) in Pulp Mills, ${ }^{102}$ and the Advisory Opinion of the International Tribunal for the Law of the Sea (ITLOS) Seabed Dispute Chamber on Responsibilities and Obligations of States Sponsoring Persons and Entities with Respect to Activities in the Area, ${ }^{103}$ the Tribunal in the South China Sea Arbitration clarified that these obligations required the coastal State to exercise due diligence in the sense of adopting relevant environmental measures but also to exercise a certain level of vigilance in their enforcement. ${ }^{104}$ The Tribunal further elaborated that Article 192 UNCLOS imposed a due diligence obligation aimed both to prevent the harvesting of species recognised internationally as threatened with extinction, and to prevent 'harms that would affect depleted, threatened, or endangered species indirectly through the destruction of their habitat.'105 Offshore energy projects are reasonably expected to pose risks of significant harm to the marine environment. In view of that risk, according to the SCS Award, States are vested with a positive duty pursuant to Article 192 UNCLOS to 'prevent or at least mitigate significant harm to the environment when pursuing large-scale construction activities.'106

Moving from substantive to procedural obligations, ${ }^{107}$ to preserve and protect the marine environment, the Arbitral Tribunal in the SCS Award also put forward a brief analysis of Article 206 UNCLOS regarding the obligation of States to conduct an environmental impact assessment (EIA) prior to authorizing activities, which may cause significant and harmful changes to the marine environment. ${ }^{108}$ Article 206 UNCLOS remains silent on the precise

\footnotetext{
101 South China Sea Arbitration (n 100) paras 941-42.

102 Pulp Mills on the River Uruguay (Argentina v Uruguay) [2010] ICJ Rep 14.

103 ITLOS, Seabed Dispute Chamber, Responsibilities and Obligations of States Sponsoring Persons and Entities with Respect to Activities in the Area (Request for Advisory Opinion Submitted to the Seabed Disputes Chamber) (Advisory Opinion, 1 February 2011) ITLOS Reports 2011.

104 South China Sea Arbitration (n 100) para 944.

105 ibid paras 941-42.

106 ibid para 941.

107 The ICJ has made a distinction between procedural and substantive obligations to protect the environment, see Pulp Mills (n 102) para 79; Certain Activities Carried Out by Nicaragua in the Border Area (Costa Rica v Nicaragua)/Construction of a Road in San Juan River in Costa Rica (Nicaragua v Costa Rica) (Merits) [2015] ICJ Rep 665, para 101.

108 South China Sea Arbitration (n 100) paras 987-91.
} 
content of an EIA and, in general, falls short of meeting the current customary law standards spelled out by the ICJ in the Pulp Mills and Construction of a Road/Certain Activities cases. ${ }^{109}$ That is because Article 206 UNCLOS only requires such EIAs to be conducted 'when states have reasonable grounds for believing that planned activities under their jurisdiction or control may cause substantial pollution of or significant and harmful changes to the marine environment.'110

In that sense, the provision of Article 206 UNCLOS can be interpreted as granting the coastal State the discretion to avoid conducting an EIA when it does not have 'reasonable ground' to believe that the planned activities can pose a significant harm to the marine environment. While there is no doubt that offshore energy installations qualify as activities that may cause such pollution, and therefore require an EIA, it is evident that Article 206 UNCLOS needs to be read in light of the customary law obligation and any other relevant instrument, such as the Espoo Convention. ${ }^{111}$ As a matter of fact, offshore energy installations create a 'risk of significant transboundary harm, which would trigger the requirement to carry out an environmental impact assessment ${ }^{\prime 112}$ as an expression of the obligation of due diligence. ${ }^{113}$

In the view of the ICJ, an EIA must be conducted prior to the implementation of the project. ${ }^{114}$ In addition, once a project has started, 'continuous monitoring of its effects on the environment shall be undertaken' throughout the life of the project. ${ }^{115}$ Against the backdrop of the precautionary principle and the duty of prevention, ${ }^{116}$ there is an obligation of the host State to revisit

109 Gavouneli (n 90) 195; Pulp Mills (n 102) para 101; Costa Rica v Nicaragua (n 106) para 104.

110 The Convention on Environmental Impact Assessment in a Transboundary Context (adopted 25 February 1991, entered into force 10 September 1997) 1989 UNTS 309 (Espoo Convention) art 2(2) requires to conduct an EIA even if risks are uncertain and potential harm is not necessarily irreparable.

111 UNCLOS, art 237 allows for the application of relevant international environmental agreements in the context of the protection of marine environment. Concerning EIAs, the 1991 Espoo Convention ( $\mathrm{n}$ 110) is particular relevant. Notwithstanding the regional ambit of the Espoo Convention, in the case of Nord Stream pipeline the states concerned have invoked its provisions, which substantiate on the elements of an adequate EIA; see Sergei Vinogradov, 'Challenges of Nord Stream: Streamlining International Frameworks and Regimes for Submarine Pipelines' (2009) $5^{2}$ German YBIL 241.

112 Costa Rica v Nicaragua (n 108) para 104.

113 Stephens and French ( 6 6).

114 Pulp Mills (n 102) paras 203-4.

115 ibid para 205.

116 Rio Principle 15 states that '[i]n order to protect the environment, the precautionary approach shall be widely applied by States according to their capabilities. Where there are threats of serious or irreversible damage, lack of full scientific certainty shall not be used 
the initial EIA in order to monitor the effects of a long-term project on the environment. ${ }^{117}$ This is of utmost importance in the case of investments in offshore energy production ${ }^{118}$ as offshore energy installations are always longterm and capital-intensive investments. During the long-life cycle of such investments, environmental changes or advances in scientific awareness about the impacts of the technology used to produce offshore energy can necessitate the alteration of the legal environment under which the investments in question operate. Therefore, it becomes evident that the need to protect the marine environment, which often translates into stricter environmental regulation of economic activities at sea, might negatively affect offshore energy investments.

\subsection{The Challenge of Balancing Environmental Regulation and Investment Protection}

The risk of changes in environmental regulations pursuant to which energy investments operate, poses challenges to the stability of the relationship between the host State and investors. The potential for conflict between environmental and investment protection is vividly illustrated in a considerable number of investment disputes which have an environmental aspect. ${ }^{119}$ Investors have usually complained that the enactment of stricter environmental regulations during the operation of an offshore energy investment, or the refusal of a permit for an offshore energy project on allegedly environmental grounds constitutes breach of an IIA. ${ }^{120}$

The same holds true in respect of the disputes that concern the marine environment. For instance, in the pending ICSID proceedings in Rockhopperv Italy, an offshore oil and gas company claims a breach of fair and equitable treatment (FET) under Article 1o ECT following the denial by Italy of a production

as a reason for postponing cost-effective measures to prevent environmental degradation.', see United Nations Conference on Environment and Development, 'Rio Declaration on Environment and Development' (14 June 1992). Regarding the legal nature of the principle or approach, see inter alia Arie Trouwborst, 'The Precautionary Principle in General International Law: Combating the Babylonian Confusion' (2007) 16(2) RECIEL 185.

117 UNCLOS, art 204(2).

118 ITLOS, Dispute Concerning Delimitation of the Maritime Boundary Between Ghana and Côte d'Ivoire in the Atlantic Ocean, ITLOS Case No 23, Order of 25 April 2015 (Provisional Measures) dispositif, para $1(\mathrm{c})$.

119 See Joshua Paine, 'Failure to Take Reasonable Environmental Measures as a Breach of Investment Treaty?' (2017) 18 JWIT 745-746.

120 See, for example, William Ralph Clayton, William Richard Clayton, Douglas Clayton, Daniel Clayton and Bilcon of Delaware, Inc $v$ Canada, PCA Case No 2009-04, Award on Jurisdiction and Liability (17 March 2015); Crystallex International Corp v Bolivarian Republic of Venezuela, ICSID Case No ARB(AF)/11/2, Award (4 April 2016). 
concession in the Ombrina Mare field in the Italian territorial sea. ${ }^{121}$ Following the identification of a hydrocarbon deposit in that area, which was authorized under an exploration permit by the Italian authorities, the company applied for a production concession. However, while the application was under scrutiny, the Italian Government adopted a new law that made the exploitation of the field unfeasible, due to its proximity to a natural reserve area. ${ }^{122}$ While the ECT does not oblige States to open up their natural resources extraction to foreign investors, and therefore the protection afforded to the stage before the pre-establishment phase of an investment is rather weak, it remains to be seen whether Italy had created legitimate expectations of the investor by way of its representations.

Similar issues can arise with regard to marine renewable energy projects. Specifically, scientific knowledge concerning the impact on the marine environment of full-scale commercial exploitation of renewable technologies is currently scarce due to the early stage of their development. ${ }^{123}$ Yet, as scientific knowledge regarding the risks posed by offshore renewable energy technologies increases, States will be under stricter due diligence obligations to take all necessary measures to protect the marine environment against those risks. At the same time, investors will continue to pursue their economic interests, which require a stable and predictable legal environment. Given the uncertainty created by changes in environmental regulation, the friction between these competing interests seems inevitable and the search for legal tools able to address this friction will become pressing in the future.

Marine spatial planning (MSP) could serve as an efficient tool to align the competing interests of the protection of the marine environment, on the one hand, and the protection of investments, on the other. Among the most significant challenges posed to the current international legal framework regulating economic activities at sea is the need to balance the various uses of the sea, without disregarding the urgent need to protect and preserve the marine environment. The increasing need for maritime space for different purposes, such as navigation, fisheries, and installations for the production of energy from renewable sources, and oil and gas exploration and exploitation, requires

\footnotetext{
121 Rockhopper Exploration Plc, Rockhopper Italia SpA and Rockhopper Mediterranean Ltd v Italian Republic, ICSID Case No ARB/17/14 (pending) <http://investmentpolicyhub.unctad.org/ISDS/Details/80o> accessed 13 May 2018.

122 Danilo Ruggero Di Bella 'Rockhopper vs Italy: Weighing Legitimate Expectations Up Against Investor's Due Diligence in M\&A Deals' (Kluwer Arbitration Blog, 27 January 2018) $<$ http://arbitrationblog.kluwerarbitration.com/2018/01/27/rockhopper-vs-italy-weighinglegitimate-expectations-investors-due-diligence-ma-deals/> accessed 13 May 2018.

Trevisanut (n 1) 261-63.
} 
the adoption of an integrated approach to marine spatial management. With a view to safeguarding the sustainable coexistence of sometimes competing uses in multifunctional maritime zones, MSP can play a significant role as an inclusive regulatory tool for decision-making for the host State of the investment. The fragmented, heavily sectoral approach in the regulation of different ocean uses has had negative implications for the development of the offshore energy industry. ${ }^{124}$ The lack of marine planning creates legal ambiguity about the appropriate location of energy installations at sea and this can constitute a serious impediment for investments in capital-intensive offshore energy projects. In addition, investors in the offshore energy sector are also facing the possibility of conflict with other legitimate uses of marine spaces, such as navigation or fisheries, adding to the inherent risks in the offshore energy sector. ${ }^{125}$ In this context, MSP can operate as a procedural tool to mutually accommodate the competing uses of the oceans, and therefore support the further development of the offshore energy sector. ${ }^{126}$

\subsection{Potential Synergies: Protection of the Marine Environment in International Investment Law?}

The international obligations of States to protect and preserve the marine environment seem to have the potential to impact investment flows. ${ }^{127}$ Still, interaction between international marine environmental law and international investment law does not necessarily result in normative conflict. Recently, States are attempting to introduce environmental protection considerations in IIAs, as illustrated by the Comprehensive and Progressive Agreement for Trans-Pacific (CPTPP). ${ }^{128}$ Such provisions are aimed at preserving regulatory

124 Michaela Young, 'Building the Blue Economy: The Role of Marine Spatial Planning in Facilitating Offshore Renewable Energy Development' (2015) 30 The International Journal of Marine and Coastal Law 148, 157; Frank Maes, 'The International Legal Framework for Marine Spatial Planning' (2008) 32 Marine Policy 797.

125 Young (n 124) 157.

126 David Leary and Miguel Esteban, 'Climate Change and Renewable Energy from the Ocean and Tides: Calming the Sea of Regulatory Uncertainty' (2009) 24 The International Journal of Marine and Coastal Law 617, 646.

127 See empirical data referred to in Antoine Dechezleprêtre and Misato Sato, 'The Impacts of Environmental Regulations on Competitiveness' (2014) 15 <www.lse .ac.uk/GranthamInstitute/wp-content/uploads/2014/11/Impacts_of_Environmental_ Regulations.pdf> accessed 14 May 2018.

128 See Comprehensive and Progressive Agreement for Trans-Pacific (signed 8 March 2018) arts 9.16 and $9.17<$ www.mfat.govt.nz/en/trade/free-trade-agreements/free-trade -agreements-concluded-but-not-in-force/cptpp/comprehensive-and-progressive -agreement-for-trans-pacific-partnership-text/> accessed 8 May 2018. On the importance 
space with regard to environmental protection for the contracting States without compromising the purpose of the IIA in question. At the same time, they serve as indicators for foreign investors that the host State can take regulatory measures for the protection of the environment and they cannot safely disregard that potential risk. In a similar manner, developments in international investment law and arbitration, such as increased references to international standards of corporate social responsibility, the adjustment of the level of reasonableness expected from investors and the broad interpretation of necessity clauses, illustrate that regime interaction can also work in a mutually supportive way, ${ }^{129}$ when the objectives pursued by the different regimes are reconcilable.

For instance, the target of climate change mitigation tools fosters the development of marine renewable energy to facilitate the shift towards sustainable energy. In this context, the host State of an investment, by making international commitments to protect the marine environment, creates certain expectations that - among others - may lead investors to invest in offshore energy projects. In fact, the investor is objectively entitled to expect that the host country will act with due diligence in complying with the international obligations it has undertaken to preserve and protect the marine environment, since the marine environment is the context in which an offshore energy investment operates. By way of illustration, in the case of Bilcon $v$ Canada, ${ }^{130}$ a NAFTA tribunal accepted an investor's claim that Canada's breach of its domestic environmental law also amounted to a breach of the minimum standards of treatment of the investment in question. In particular, the Tribunal highlighted that governments are required to meet high environmental standards under NAFTA and to live up to the legitimate expectations they create for the investors. ${ }^{131}$

When it comes to investments in offshore energy production, it is important that the host State complies with its international obligations for marine safety and preparedness against accidents in order for the investments to operate smoothly. Considering the serious repercussions for the industry of the Deepwater Horizon accident, ${ }^{132}$ it is assumed that serious marine environ-

of other international environmental obligations of States, see also CPTTP, ch 20 on Trade and the Environment.

129 See Jorge E Viñuales, 'Foreign Investment and the Environment in International Law: An Ambiguous Relationship' (2010) 8o BYBIL 244, 248-54; Amelia Keene, 'International Investment Developments' (2015) 26 YBIEL 283, 292-93.

130 Clayton and Bilcon of Dalaware Incv Canada, PCA Case No 2009-04, Award on Jurisdiction and Liability (17 March 2015).

131 ibid para 738 .

132 See supra $\mathrm{n} 3$ and accompanying text. 
mental harm can hinder investments located in the marine area of a major accident. In this sense, the failure of a State to duly comply with its international obligations to protect and preserve the marine environment could frustrate the legitimate expectations of the investor, and thus, qualify as a potential breach of investment protection standards under IIAs.

In this latter scenario, investor-state arbitration has the potential to provide a forum where investors, by bringing claims against host States for breaches of investment protection standards, are indirectly bringing a claim for noncompliance with international environmental obligations. That is particularly relevant with respect to investments, whose operation requires the State to take measures to protect and preserve the surrounding environment. Using their right to initiate arbitral proceedings against States, investors could then indirectly strengthen the objectives and the enforcement of such environmental obligations. Of course, any such investment claim would necessarily be framed in the terms of the applicable IIA and the relevant investment standards contained therein. In other words, the breach of any environmental obligation would then be formulated as a breach of the obligations of the host State towards the investor, such as full protection and security (FPS) or FET. Still through the lens of investment protection, the arbitral tribunal would need to address the possible violation of the due diligence obligation of the host State to take all necessary measures to prevent the degradation of the marine environment when such failure has caused damage to the investment. ${ }^{133}$

A situation of this kind recently arose in the case of Peter Allard $v$ Barbados, when a Canadian investor, who owned a nature sanctuary in Barbados, brought an investment claim against the Government of Barbados. ${ }^{134}$ His claim was grounded on the alleged failure by the host State to implement its environmental law and meet its international obligations stemming from the Convention on Wetlands ${ }^{135}$ and the Convention on Biological Diversity, ${ }^{136}$

133 Kate Parlett and Sara Ewad, 'Protection of the Environment in Investment Arbitration - A Double Edged Sword' (Kluwer Arbitration Blog, 22 August 2017) <http://arbitrationblog .kluwerarbitration.com/2017/08/22/protection-environment-investment-arbitration -double-edged-sword/> accessed 14 May 2018.

134 Peter A Allard v the Government of Barbados, PCA Case No 2012-06, Award (27 June 2016).

135 Convention on Wetlands of International Importance Especially as Waterfowl Habitat (adopted 2 February 1971, entered into force 21 December 1975) 996 UNTS 245, as amended by the Paris Protocol (adopted 3 December 1982, entered into force 1 October 1986) 1437 UNTS $_{3}$, and the Amendments to Articles 6 and 7 of the Convention on Wetlands of International Importance Especially as Waterfowl Habitat (adopted 28 May 1987, entered into force 1 May 1994) 1824 UNTS 345 (Regina Amendments).

136 Convention on Biological Diversity (adopted 5 June 1992, entered into force 29 December 1993) 176o UNTS 79 . 
arguably resulting in the pollution of his eco-tourism sanctuary, thus depriving him of the value of his investment. Specifically, the investor claimed that Barbados had failed to accord to his investment FPS under the 1996 BarbadosCanada BIT, because it failed to prevent a State agency from repeatedly discharging polluted substances into the wetlands in violation of both Barbados' domestic environmental law and obligations under international environmental agreements. Furthermore, the investor claimed that Barbados had failed to provide him FET, because he had legitimate expectations that the host State would enforce its environmental friendly regulatory framework.

The Tribunal dismissed the claims and did not find any breach of the BIT.137 It however stated that 'consideration of a host State's international obligations may well be relevant in the application of the FPS standard in particular circumstances. ${ }^{\prime 38}$ This obiter dictum confirms that IIAs will interact with international environmental agreements through interpretation. As a matter of principle, the Allard award seems to raise the possibility that a State can be held liable under an IIA for failing to comply with its international environmental obligations. ${ }^{139}$ In other recent awards, arbitral tribunals have also noted that international rules are sometimes relevant to determining the legitimate expectations of investors. ${ }^{140}$ It remains to be seen what the implications of the Allard case will be for future claims raised by investors complaining that the host State has failed to protect the marine environment or to implement climate change mitigation measures, when such measures for example could affect the operation of offshore energy investments. In that sense, investment protection has the potential to foster compliance with environmental obligations by the host State, illustrating the bright side of regime interaction.

Furthermore, it is also posited that investment protection is not always negatively affected by the enforcement of strict environmental measures, as investment and environmental protection are not always competing with each other. As has been noted, the failure of a State to comply with its international environmental obligations can under certain circumstances qualify as a breach of IIAs. If a host State acts against its international obligations under

137 The Tribunal found that Barbados had taken appropriate and sufficient measures to protect the nature sanctuary, including conducting research and seeking to balance competing needs, see Allard $v$ Barbados (n 134) paras 245-49.

138 ibid para 244

139 See Paine (n 120) 746.

140 Philip Morris Brands Sarl, Philip Morris Products SA \& Abal Hermanos SA v Oriental Republic of Uruguay, ICSID Case No ARB/10/7, Award (8 July 2006) para 430; Glamis Gold $L t D v$ United States of America, UNCITRAL/NAFTA, Award (8 June 2009) para 767. 
the law of the sea and international environmental law, it might compromise the protection of investments and produce significant economic harm. Such a situation could occur for instance when a State that has authorized an investment has overlooked its procedural environmental obligations, such as the duty of notification and consultation with the affected State(s), or the prior conduct of adequate EIAs before authorizing the affected investment.

The Pulp Mills case between Argentina and Uruguay offers a paradigmatic example of the problem. ${ }^{141}$ The dispute concerned two pulp mills constructed in Uruguayan territory on the banks of the River Uruguay, which marks the border between Argentina and Uruguay. Argentina initiated proceedings before the ICJ alleging breaches by Uruguay of the 1975 Statute of the River Uruguay, more specifically the obligation of notification, consultation and conduct of an EIA, as well as substantive obligations of environmental protection under the Statute and customary international law. Even though in this particular case Uruguay won the case before the ICJ, it becomes evident from the investor's standpoint that the possibility of an inter-State dispute concerning compliance with inter-State environmental obligations constitutes a noncommercial risk and the actual protection of the investment might depend on the outcome of the dispute.

Relatedly, in case the host State is found to have breached its international environmental obligations by authorizing an investment in offshore energy generation, it could be obliged to ensure that all activities related to that investment cease. That, of course, would have a negative impact on the investment. Therefore, investors in offshore energy production should be aware of the international legal context in which their investments operate in order to assess the risk that their investment may be involved in a time-consuming interstate dispute. To minimize this risk, it is crucial that the investor ensures that the host State has complied with international legal requirements regarding his/her investment, including an authorization regime providing for a proper EIA. In other words, the exercise of due diligence in protecting the marine environment by the host State can safeguard the undisturbed operation of offshore energy investments.

141 Pulp Mills (n 102). See case comment by Ilias Plakokefalos, 'The Pulp Mills Case' (2011) 26 The International Journal of Marine and Coastal Law 169. 


\section{4 \\ The Impact of Non-Investment Interstate Dispute Settlement Mechanisms on Investment Protection}

As highlighted in the previous Part, the law of the sea and relevant environmental agreements and instruments create obligations for States to protect and preserve the marine environment. State compliance with those international obligations can sometimes create non-commercial risks for foreign investments, inter alia, when such compliance requires States to enact stricter environmental rules and standards regarding the operation of the said investments. In this context, the possibility of an interstate dispute can entail noncommercial risks. These risks increase when investments are located in disputed maritime areas or in areas where resources are disputed.

Offshore energy exploitation has been the underlying issue in a considerable number of maritime delimitation disputes since the North Sea Continental Shelf cases in $1969 .{ }^{142}$ While the absolute suspension of energy exploitation goes against the economic interests of the States concerned, any unilateral activity within a disputed maritime area is likely to produce tensions escalating into intergovernmental disputes. ${ }^{143}$ In case of overlapping EEZ and continental shelf claims, UNCLOS ${ }^{144}$ dictates that States involved are under a positive obligation to make every effort to enter into provisional arrangements of a practical nature and also under a negative one to make every effort, in good faith, not to jeopardize or hamper reaching a final agreement. These two obligations 'simultaneously attempt to promote and limit activities in a disputed maritime area.' ${ }^{\prime 45}$

The nature and content of these obligations, ${ }^{146}$ to enter into provisional arrangements and not to hamper reaching final arrangements, are addressed in

142 North Sea Continental Shelf Cases (Federal Republic of Germany/Denmark; Federal Republic of Germany/Netherlands), Judgment (20 February 1969) ICJ Rep 1969, 3.

143 Tara Davenport, "The Exploration and Exploitation of Hydrocarbon Resources in Areas of Overlapping Claims' in Robert Beckman and others (eds), Beyond Territorial Disputes in the South China Sea: Legal Frameworks for the Joint Development of Hydrocarbon Resources (Edward Elgar 2013) 93, 100.

144 UNCLOS arts 74(3) and 83(3) read: "The States concerned, in a spirit of understanding and cooperation, shall make every effort to enter into provisional arrangements of a practical nature and during the transitional period, not to jeopardize or hamper the reaching of final agreement. Such arrangements shall be without prejudice to the final delimitation'.

145 Guyana v Suriname, PCA Case No 2004-04, Award (17 September 2007) para 459.

146 Yoshifumi Tanaka, 'Unilateral Exploration and Exploitation of Natural Resources in Disputed Areas: A Note on the Ghana/Cote D'Ivoire Order of 25 April 2015 Before the Special Chamber of ITLOS' (2015) 46 Ocean Dev \& Intl L 315, 315-16. 
the 2007 case between Guyana and Suriname. ${ }^{147}$ In this case, a delimitation agreement was pending when Guyana issued oil exploration concessions in the disputed area. Suriname had demanded that Guyana cease all oil exploration activities in the area and, eventually, Suriname used its naval force to oblige an oilrig and drillship, owned by Guyana's concessionaire, to leave the contested area. Pending the arbitral proceedings, drilling activities in the area had to be suspended, causing economic harm to the investor.

The Arbitral Tribunal had to strike a delicate balance between preventing economic activities that affect the other party's rights in an irreparable manner and, at the same time, not stifling the parties' ability to pursue economic activities in a disputed area during a time-consuming boundary negotiation. ${ }^{148}$ The Tribunal stressed that a distinction should be made between activities that lead to a permanent physical change and, thus, can prejudice the final arrangements, and those that do not, such as seismic exploration. ${ }^{149}$ It found that authorizing drilling activities in disputed maritime areas was a breach of the obligation to make every effort not to hamper or jeopardize the reaching of final agreements, as this could result in a physical change to the marine environment. ${ }^{150}$ It concluded that 'it should not be permissible for a party to a dispute to undertake any unilateral activity that might affect the other party's rights in a permanent manner. ${ }^{\prime 151}$ A State must first inform, notify and consult the other State if it is carrying out unilateral exploration and/or exploitation of natural resources in a disputed maritime area. ${ }^{152}$

Similarly, in the dispute between Ghana and Côte d'Ivoire, ${ }^{153}$ an ITLOS Special Chamber was faced with a balancing exercise between the protection of the marine environment, the protection of Ghana's economic interests (which had granted offshore energy concessions in the disputed area) and Côte d'Ivoire's claimed exclusive sovereign rights to explore and exploit the resources in the disputed area. According to Ghana, while there was no definitive written treaty between the parties delimiting the continental shelf or the EEZ, both parties had followed, since the 196os, the shared practice of authorizing oil and gas exploration and exploitation activities in their adjacent offshore areas on the basis of an equidistance line. Still according to Ghana, it was

\footnotetext{
147 Trevisanut (n 1 ) 258-59.

148 Guyana v Suriname (n 145) para 470.

149 ibid para 467.

150 ibid para 480 .

151 ibid para 470 .

152 Davenport (n 144) 112.

153 Dispute Concerning Delimitation of the Maritime Boundary Between Ghana and Côte d'Ivoire in the Atlantic Ocean (Provisional Measures) (n 118).
} 
not until 2009 that Côte d'Ivoire unexpectedly changed its position and began to argue in favour of a different median line lying significantly to the East of the previous equidistance line. In its 2015 order on provisional measures, the ITLOS Special Chamber aimed to not unnecessarily stifle Ghana's ability to pursue economic development in the disputed area during a time-consuming boundary dispute and, for that reason, did not suspend the already authorised drilling activities. At the same time, it required Ghana to monitor these activities with the goal of ensuring the prevention of serious harm to the marine environment.

Surprisingly, the Special Chamber did not declare that all drilling activities were a breach of Ghana's negative obligation to refrain from hampering the final agreement. In this case, the Chamber made an important distinction between ongoing and new drilling activities. With respect to the former, the Special Chamber denied the requested suspension on the double ground that any prohibition in relation to existing activities 'would entail the risk of considerable financial loss to Ghana and its concessionaires' (economic element) and that it 'could also pose a serious danger to the marine environment resulting, in particular, from the deterioration of equipment' (environmental element). ${ }^{154}$ The Special Chamber confirmed its approach in the final delimitation judgement issued in September 2017. ${ }^{155}$ It concluded that hydrocarbons activities in a disputed area do not necessarily breach the obligation set forth in Article 83(3) UNCLOS 'not to jeopardize or hamper the reaching of the final agreement,' the main reason being that 'Ghana has undertaken hydrocarbon activities only in an area [finally] attributed to it.'156 Consequently, 'the activities of Ghana do not meet the qualification of [violation of Article 83(3) UNCLOS] since they did not take place in the Ivorian maritime area.'157

This finding departs from the approach in Guyana $v$ Suriname, where the Arbitral Tribunal ascertained the international responsibility of Guyana for a drilling activity located in the area finally attributed to it. ${ }^{158}$ In his Separate Opinion to the 2017 Special Chamber's judgement in the Ghana-Côte d'Ivoire case, Judge Paik rightly noted that 'it would be reasonable to assume that the intensive hydrocarbon activities with accompanying massive financial investment in the disputed area would have left Ghana little room for flexibility in

\footnotetext{
154 ibid para 99.

155 Dispute Concerning Delimitation of the Maritime Boundary Between Ghana and Côte d'Ivoire in the Atlantic Ocean (n 118) Judgment (23 September 2017).

156 ibid para 633 .

157 ibid.

158 Guyana v Suriname (n 145) paras 479-82.
} 
its negotiations with Côte d'Ivoire.'159 Moreover, in his Opinion, Judge Paik emphasized how Article 83(3) UNCLOS imposed an obligation to exercise 'caution and restraint' and that '[t]o exonerate acts that could jeopardize or hamper the reaching of the final agreement for the reason that the area is ultimately attributed to a State undertaking such acts would significantly diminish the value of this obligation. 160 From these two cases, the fate of hydrocarbon investments in a disputed area is still uncertain.

The recently issued award in the highly controversial dispute between the Philippines and China is also likely to have serious implications on investments in the offshore energy sector. Contrary to the previous two cases, this case was not a delimitation dispute, or at least was not phrased as such regardless of its substantial result. ${ }^{161}$ Though there was no explicit evidence in the claims made by the Philippines that the underlying competing interests of the two States in offshore energy resources triggered the dispute, the escalation of the conflict can be correlated directly to the prospects of untapped deposits of oil and natural gas in the area. ${ }^{162}$ The central issue concerned the question whether the Spratly Islands and Scarborough Reef qualified as islands according to Article 121 UNCLOS and, subsequently, whether they give rise to claims for a continental shelf and an EEZ of their own. ${ }^{163}$ For the purposes of the present article, it suffices to mention that the Tribunal declared that the contested 'features' did not qualify as islands pursuant to UNCLOS and, as result, they could not generate their own continental shelf or EEZ. Accordingly, the Tribunal stated that there is 'no possible entitlement by China to any maritime

\footnotetext{
159 Dispute Concerning Delimitation of the Maritime Boundary Between Ghana and Côte d'Ivoire in the Atlantic Ocean (Judgment) (n 155) Separate Opinion of Judge Paik, para 15. 160 ibid para 17 .

161 Due to the fact that China has excluded maritime boundary delimitation disputes from the compulsory jurisdiction mechanism under UNCLOS art 298 (see declaration under UNCLOS art 298 made by China after its ratification of the Convention in South China Sea Arbitration (n 100) para 153), the Philippines formulated its claims in a remarkably delicate manner in order to support that the dispute was a matter of interpretation and application of the Convention and substantiate the jurisdiction of the Annex VII Arbitral Tribunal; Award on Jurisdiction, paras $15^{2-54}$.

162 Gisela Grieger, 'China and the South China Sea Issue' European Parliamentary Research Service Briefing' (2016) <www.europarl.europa.eu/RegData/etudes/BRIE/2016/586671/ EPRS_BRI(2016)586671_EN.pdf $\geq$ accessed 13 May 2018; South China Sea Arbitration (n 100) para 3 .

163 Alex Oude Elferink, 'The South China Sea Arbitration's Interpretation of Article 121(3) of the LOSC: A Disquieting First' (2016) <http://site.uit.no/jclos/2016/og/o7/the-south -china-sea-arbitrations-interpretation-of-article-1213-of-the-losc-a-disquieting-first/> accessed 13 May 2018.
} 
zone in the area, ${ }^{\prime 164}$ but the contested area falls within the EEZ and continental shelf of the Philippines. ${ }^{165}$ Starting from this presumption, it further held that China's activities ${ }^{166}$ within the contested area breached, among others, the Philippines' exclusive sovereign rights to explore and exploit its non-living natural resources. ${ }^{167}$ Moreover, it found that the constructions and artificial islands built by China in the maritime area manifestly breached the Philippines' exclusive right to authorize and regulate such constructions under Articles $5^{6}$ and 60 UNCLOS. ${ }^{168}$

Even though the final award is binding upon both States, ${ }^{169}$ China publicly communicated that it did not accept or recognize the award. ${ }^{170}$ Surveys conducted in the marine area have shown that it is a rich natural gas reserve. ${ }^{171}$ Thus, China may renew or expand its efforts to explore and exploit energy resources in the area. Reportedly, China has approved plans for a mobile deepsea platform to look for minerals in the South China Sea. ${ }^{172}$ Apparently, State practice in the aftermath of the award will have a spill-over effect on future and already made offshore energy investments in the region. Since it is recognized by the arbitral award that the marine area is within the Philippines' EEZ and continental shelf, any investment authorised by China runs severe legal risks. Conversely, the Philippines will have a hard time offering protection to promote offshore energy investments in the region, as long as China does not recognize its exclusive sovereign right to exploit natural resources in the area in question. ${ }^{173}$ This situation clearly undermines the legal certainty and predictability necessary for investors in offshore energy production in the area.

\footnotetext{
164 South China Sea Arbitration (n 100) para 646.

165 ibid para 647 in fine.

166 China interfered with the Philippines' oil exploration activities, ibid paras 707-8.

167 ibid para 716 .

168 ibid paras $1033^{-} 38$.

169 UNCLOS, art 296.

170 People's Republic of China, State Council, 'China Adheres to the Position of Settling Through Negotiation the Relevant Disputes Between China and the Philippines in the South China Sea' (2016) <http://english.gov.cn/state_council/ministries/2016/07/13/ content_281475392503075.htm> accessed 14 May 2018.

171 Youna Lyons, 'Offshore Oil and Gas in SCS and the Protection of the Marine Environment' (2011) <https://cil.nus.edu.sg/research-projects/ocean-law-policy/offshore-installations/ pollution-from-offshore-activities/> accessed 14 May 2018.

172 'China Is Planning a Massive Sea Lab 10.000 Feet Underwater' (Bloomberg, 8 June 2016) $<$ www.bloomberg.com/news/articles/2016-06-07/china-pushes-plan-for-oceanic-space -station-in-south-china-sea> accessed 14 May 2018.

173 'Philippine's Oil Still in Trouble After South China Sea Ruling' (Reuters, 22 July 2016) $<$ www.reuters.com/article/us-southchinasea-ruling-philippines-ener-idUSKCN1020HK> accessed 14 May 2018.
} 
The implications of the arbitral award for investors may be much broader and reach far beyond the South China Sea region. Particularly, the interpretation of Article 121 UNCLOS on what constitutes an island could initiate further inter-State disputes regarding similar features, which had been until now regarded as islands by the States concerned. ${ }^{174}$ As noted above, only a 'real' island can generate its own EEZ and continental shelf, within which the coastal State enjoys exclusive sovereign rights to explore and exploit energy resources. In case such disputes arise, the offshore energy investments already operating within those maritime areas are expected to face critical non-commercial risks.

More generally, non-investment inter-State disputes have the potential to directly bear consequences not only on the investments planned or performed in the specific disputed area. Their judicial settlement potentially impacts investments in other areas of the world as they amount to an authoritative statement of the law. For instance, the restrictive interpretation of what constitutes an island under Article 121 UNCLOS could be further applied in other disputed marine areas, which in turn could have repercussions on the entitlement of host States to authorize offshore energy activities in those areas. In that manner, the law of the sea interacts with the protection of investments which might suffer from the outcome of such an inter-State maritime boundary dispute but might also strengthen its legal position thanks, for instance to the final delimitation of maritime zones between neighbouring States.

Offshore energy investments are at the intersection of overlapping international regimes, which are inspired by divergent objectives. International law supports and needs to accommodate competing challenges simultaneously, such as to provide clean and affordable energy to meet the ever-growing global demand, while protecting the marine environment and responding to climate change. Should then investments in marine renewable energy production, for example, be treated any differently compared to the exploitation of fossil fuels? How can the competing interests of marine environmental protection and investment protection that interact in the regulation of offshore energy production be accommodated in international investment law? Is there a need for the reform of IIAs to that end? Is a pluralistic accommodation an alternative to hierarchy?

174 It is stressed that the Arbitral Award does not bind third States and there is no principle of 'stare decisis' in international law. Yet, such awards are considered secondary sources of international law, see ICJ Statute, art $38(1)(d)$. 
In these concluding remarks, we will try to answer some of those questions from the perspective of international investment law. As we posited in the Introduction, we think that international investment law can largely benefit from accommodating interests protected by the other applicable regimes, while safeguarding its own distinct interests.

As shown in this article, the law of the sea, environmental and climate change law can pose challenges to investment protection. However, they are not necessarily a 'threat' to investment protection. As shown in the first part of the article, for example, IIAs, by interacting with the law of the sea, can expand their territorial application, if not explicitly provided by the agreements, to marine areas, such as the EEZ and an extended continental shelf. That is in line IIAs' object and purpose, which primarily are to provide wider protection to investments and cultivate economic cooperation. Moreover, referring explicitly to the relevant rules of the law of the sea, IIAs incorporate any subsequent development in the law of the sea, which might influence the maritime areas over which the coastal State exercises jurisdiction.

As discussed in the second part of this contribution, international environmental law is an increasingly important source of regulation for investments in the offshore energy sector. The changes in the domestic law that new international instruments require might indeed have some disruptive consequences for investments. But they can also consist of new investment opportunities ${ }^{175}$ or add to legal stability for investments. Consider, for instance, the introduction at the domestic level of regulatory tools, such as MSP. Through MSP, already existing investments will be taken into account by the competent authorities of the coastal State when authorizing any new activity in the same area. MSP will also allow already present foreign investors to be part of the decision-making process.

The third part of our contribution highlighted how non-investment interstate disputes can impact investments, in particular investments located in a disputed maritime area. The impact can of course be negative when the judicial decision requires the suspension of on-going economic activities. The consequences can however also be positive as the clarification of the territorial entitlements decreases non-commercial risks for investors who have invested in the territory of the prevailing State party to the dispute.

Each of the analysed regimes has its own mandate and seems to seek its own overarching objectives, which can create obstacles to their smooth interaction. Those seemingly competing objectives can however be, if only partially sometimes, reconciled through their interaction. Regime interaction brings

175 See the above analysed case Allard $v$ Barbados (n 134). 
together and widens the objectives of each single regime, vividly illustrating the function of international law as 'a method for doing things more than a method for settling disputes' or conflicts. ${ }^{176}$ In the case of investment protection of offshore energy investments, the interaction with the law of the sea and international environmental law pushes investment law beyond its traditional focus on the protection of investments in order to strengthen its objectives of protection and cooperation.

176 Vaughan Lowe, 'The Function of Law in the International Community: Opening Plenary Session' in James Crawford and Margaret Young (eds), 'The Function of Law in the International Community: An Anniversary Symposium - Proceedings of the 25th Anniversary Conference of the Lauterpacht Centre for International Law' (2008), as reported by Surabhi Ranganathan, Strategically Created Treaty Conflicts and the Politics of International Law (CUP 2014) 368. 